\title{
EKSISTENSI BUDAYA MEGOAK-GOAKAN DALAM MEMPENGARUHI AKUNTANSI KHUSUSNYA PENGELOLAAN DANA DI DESA PANJI
}

\author{
Luh Juniawati, Kadek Ita Armini, I.G.A Ayu Puspa Priani, IMAM WAHYUDI, \\ Ni Wayan Suti Ardani, Ni Kadek Ita Erawati \\ Jurusan Akuntansi, Universitas Pendidikan Ganesha, Singaraja, Bali, Indonesia
}

\begin{abstract}
Abstrak
Penelitian ini bertujuan untuk mengetahui eksistensi nilai-nilai budaya kebersamaan dalam pembangunan untuk praktik akuntansi atau pengelolaan keuangan di Desa Panji dan bagaimana prosedur budaya megoak-goakan mempengaruhi praktik akuntansi atau pengelolaan keuangan di Desa Panji. Dari hasil penelitian Budaya megoak-goakan sangat berpengaruh terhadap eksistensi penerapan akuntansi secara umum baik dilihat secara teoritis dan praktis. terdapat nilai sosial dan nilai agama (religius). Nilai sosialnya tercermin dari perilaku masyarakat Desa Panji yang masih menjalankan prinsip gotong royong dalam kehidupan bermasyarakat. Nilai religius dari tarian ini dapat dilihat ketika akan mementaskan tarian megoak-goakan, Teruna Goak melakukan persembahyangan terlebih dahulu di Pura Pajenengan yang dipercaya merupakan tempat peristirahatan Ki Barak Panji Sakti.
\end{abstract}

Kata kunci: Budaya, Akuntansi, Pengelolaan Dana

This study aims to determine the existence of shared cultural values in development for accounting or financial management practices in Panji Village and how the megoak-cultural culture procedures affect accounting practices or financial management in Panji Village. From the results of the research, the culture of goo-goakan is very influential on the existence of the application of accounting in general, both theoretically and practically. there are social values and religious values (religious). Its social value is reflected in the behavior of the Panji Village community who still carry out the principle of mutual cooperation in social life. The religious value of this dance can be seen when performing the megoak-goakan dance, Teruna Goak conducts prayers first at Pajenengan Temple which is believed to be the resting place of Ki Barak Panji Sakti.

Keywords : Culture, Accounting, Fund Management

\section{Pendahuluan}

Budaya merupakan faktor lingkungan yang paling kuat mempengaruhi sistem akuntansi suatu daerah (Zaitul, 2003). Standar akuntansi bersifat Prinsiples-based yang berarti bahwa standar akuntansi tidak bersifat ketat atau rigid, melainkan hanya memberikan prinsip-prinsip umum standar akuntansi yang harus diikuti untuk memastikan pencapaian kualitas informasi, seperti relevan, dapat diperbandingkan, dan objektif. Oleh karena itu, para aktor akuntansi bisa memilih teknik-teknik yang digunakan selama masih dalam kaidah akuntansi berterima umum (Sinarwati, 2013:139).

Dalam kaitannya dengan pemilihan teknik-teknik standar akuntansi yang berlaku umum, berikut dipaparkan teori-teori budaya mempengaruhi perilaku :

1. Teori Fungsionalisme

Teori ini dikembangkan oleh Brownislaw Malinowski (1884-1942) yang selama perang dunia II mengisolir diri bersama penduduk asli pulau Trobian untuk mempelajari cara hidup mereka dengan jalan melakukan observasi berperan serta (participant observation). la mengajukan teori fungsionalisme, yang berasumsi bahwa semua unsur kebudayaan merupakan bagian-bagian yang berguna bagi masyarakat dimana unsur-unsur tersebut terdapat. Dengan kata lain, pandangan fungsional atas kebudayaan menekankan bahwa setiap pola tingkah laku, setiap kepercayaan dan sikap yang merupakan bagian dari 
kebudayaan suatu masyarakat, memerankan fungsi dasar di dalam kebudayaan yang bersangkutan.

2. Teori psikologis

Yakni teori yang berdasarkan pada faktor-faktor psikologis setiap individu akibat pengaruh dari kekuatan lingkungan. Bidang psikologis bisa dikatakan sangat kompleks dalam menganalisa perilaku ekonomi, oleh karena itu proses mental tidak bisa diambil secara langsung.

3. Teori antropologis

Yakni teori yang menekankan pada perilaku pembelian oleh suatu kelompok masyarakat.

Setiap daerah yang berada di Indonesia memiliki keberagaman budaya. Keberagaman budaya ini dipengaruhi oleh letak geografis, adat istiadat, agama, kebiasaan, tradisi dan suku. Selain itu faktor lingkungan juga mempengaruhi keberagaman budaya tersebut (Kementerian Pendidikan dan Kebudayaan, 2013). Seperti halnya di Bali yang terkenal dengan keberagaman budayanya sehingga disetiap daerah di Bali memiliki budaya yang berbeda-beda, salah satunya di Desa Panji, Kecamatan Sukasada, Kabupaten Buleleng yang memiliki sebuah budaya yang telah dikenal, yaitu tarian (permainan) Magoak-goakan. Tarian magoak-goakan erat hubungannya dengan sejarah penyerangan Ki Gusti Ngurah Panji Sakti Raja Buleleng ke Blambangan Jawa Timur. Dalam arsip Sejarah Buleleng Nomer: $A 1 / 263$ nilai yang terkandung dari tarian Magoak-goakan itu sendiri yaitu kebersamaan dalam pembangunan. Selain itu nilai yang terkandung adalah nilai seni dan nilai budaya. Dimana nilai seni ini tidak diperuntukan untuk mencari keuntungan melainkan menunjukkan keindahan kebersamaan yang dipresentasikan dalam sebuah tarian (permainan). Nilai Budaya dimana nilai-nilai yang disepakati dan tertanam dalam suatu masyarakat. Desa Panji adalah desa yang terletak di wilayah Bali utara tepatnya berada di Kecamatan Sukasada, Kabupaten Buleleng, Provinsi Bali, Indonesia. Total jumlah penduduk pada tahun 2009 adalah 8.537 jiwa dan total kepala keluarga 2.262 jiwa. Luas desa $1061 \mathrm{Ha}$. Terletak pada ketinggian 20m- 650m diatas permukaan laut. Masyarakat Desa Panji bekerja di sektor pertanian, perkebunan, peternakan, pegawai pemerintah, pedagang, dan swasta. Di desa ini terdapat tujuh banjar dinas, delapan subak, serta satu karang taruna. Desa Panji berbatasan dengan desa-desa lain. Sebelah utara berbatasan dengan Desa Bhakti Seraga, sebelah selatan dengan Desa Wanagiri, sebelah barat dengan Desa Panji Anom, dan di sebelah timur berbatasan dengan Desa Sambangan. Adapun latar belakang kami memilih Desa Panji sebagai tempat penelitian adalah sebagai berikut: 1) Desa Panji mempunyai sejarah yang panjang karena Desa panji mempunyai hubungan erat dengan raja Buleleng (Ki Barak Panji Sakti), 2) Desa panji mempunyai kearifan lokal yang unik dan banyak dikenal oleh masyarakat luas yaitu tarian megoak-goakan dan Desa Panji merupakan tempat lahirnya tarian tersebut, sampai sekarang kebudayaan tersebut masih dijaga kelestariannya dengan dipentaskan setiap perayaan hari-hari tertentu.

Dewasa ini pengaruh budaya terhadap sistem akuntansi merupakan isu yang banyak dibicarakan oleh berbagai pihak khususnya oleh akademisi dan praktisi. Isu tersebut menyangkut apakah budaya mempengaruhi akuntansi atau sebaliknya akuntansi mempengaruhi budaya (Zaitul, 2003). Contoh budaya yang mempengaruhi akuntansi, yaitu:

1. Budaya Tri Hita Karana memengaruhi keyakinandiri atas komputer. Bukti empirik ini konsisten dengan hasil penelitian Srite et. al. (2008).

2. Budaya Tri Hita Karana memengaruhi keinovatifan personal. Bukti empirik ini konsisten dengan hasil penelitian Srite et. al. (2008).

3. Budaya Tri Hita Karana memengaruhi penggunaan Sistem Informasi Akuntansi. Bukti empirik ni mendukung visi pembangunan Provinsi Bali tahun 2006-2026, yakni: "Bali Dwipa Jaya, Adil dan Demokratis, serta Aman dan Bersatu, dalam Wadah Negara Kesatuan Republik Indonesia Berlandaskan Tri Hita Karana".

4. Budaya Tri Hita Karana memahami penggunaan Sistem Informasi Akuntansi dimediasi oleh keyakinan-diri atas computer, keinovatifan personal, persepsi kegunaan, dan persepsi kemudahan penggunaan. 
Berdasarkan latar belakang diatas, permasalahan yang dapat dirumuskan adalah bagaimana eksistensi nilai-nilai budaya kebersamaan dalam pembangunan untuk praktik akuntansi atau pengelolaan keuangan di Desa Panji dan bagaimana prosedur budaya megoak-goakan mempengaruhi praktik akuntansi atau pengelolaan keuangan di Desa Panji.

\section{Hasil dan Pembahasan}

\subsection{Gambaran Umum Lokasi Penelitian}

Secara umum bahwa sejarah cikal bakal Desa Panji berawal dari zaman pemerintahan Dalem Segening di Kerajaan Klungkung, Bahwa pada masa itu raja Dalem Segening telah melakukan hubungan gelap dengan seorang selirnya yang benama Ni Luh Pasek yang konon dia (Ni Luh Pasek) berasal dari wilayah Bali Utara (sekarang Buleleng). Dari hasil hubungannya tersebut lahirlah seorang sentana (anak) yang diberi nama I Gusti Gede Pasekan (Ki Barak). Sebagaimana legenda yang masih dipercaya sampai saat ini, bahwa pada saat kelahirannya (I Gusti Gede Pasekan) menunjukan ciri-ciri yang sangat menonjol yakni pada saat Ki Barak tidur, sang raja melihat cahaya yang memancar dari ubun-ubun (pabaan) Ki Barak. Melihat pertanda tersebut akhirnya sang raja memanggil penasehat istana serta menanyakan tentang apa arti pertanda tersebut. Akhirnya menurut pengamatan spiritualnya, penasehat istana mengatakan bahwa kelak dia (Ki Barak) akan menjadi orang yang berpengaruh dan berkuasa di jagat ini. Rupa-rupanya hal ini menimbulkan keresahan dalam hati sang raja tentang keutuhan kerajaan di kemudian hari. Akhirnya atas saran dari penasehat istana,maka raja Dalem Segening memutuskan untuk mengirim Ki Barak ke Bali Utara, disamping untuk menghindari perpecahan di dalam kerajaan keputusan ini juga sebagai sebuah tindakan politis dalam perluasan kekuasaan nantinya. Sehingga pada saat Ki Barak genap berumur 15 tahun kemudian raja Dalem Segening memerintahkan Ki Barak untuk pergi ke Bali Utara. Hingga pada akhirnya dia sampai dan menetap di Desa Panji. Pada saat dia sampai di Desa Panji, di Desa Panji sudah berdiri sebuah kerajaan kecil yang diperintah oleh seorang raja yang sangat bengis yang bernama Ki Pungakan Gendis. Sebuah momen yang sangat penting dalam perjalan sejarah Desa Panji adalah adanya sebuah sayembara besar untuk menolong sebuah kapal laut besar milik seorang pengusaha dari Cina yang karam di Segara Penimbangan. "Barang siapa yang dapat mengembalikan/mendorong kapal tsb ke tengah laut, maka semua isi kapal tsb akan dihadiahkan kepadanya." Masyarakat berbondong-bondong untuk mengikuti sayembara tersebut namun tidak ada yang berhasil termasuk Ki Pungakan Gendis. Akhirnya Ki Barak pun ikut dalam sayembara tersebut, dengan kemampuan gaib sebilah keris yang dibawanya dia mengacungkan tangannya kearah kapal tersebut, dan perlahan-lahan kapal tersebut bergerak ketengah, seketika itu masyarakat yang menyaksikan bersorak mengelukelukan Ki Barak dan pedagang Cina itu pun memberikan semua isi kapalnya yang berupa emas, berlian, kain, beras dan lain sebagainya sehingga membuat Ki barak menjadi kayaraya.Melihat prestasi gemilang serta dukungan rakyat yang semakin besar terhadap Ki Barak, maka Ki Pungakan Gendis kian murka hingga pada akhirnya memutuskan untuk melakukan peperangan dengan Ki Barak dan akhirnya Ki Pungakan Gendis tewas dan peperangan dimenangkan oleh Ki Barak. Dengan gugurnya Raja Pungakan Gendis itu,maka mulai lah era pemerintahan baru di bawah kekuasaan I Gusti Gede Pasekan Yang kemudian dikenal sebagai I Gusti Ngurah Panji Sakti yang setelah dinobatkan menjadi raja bergelar Anglurah Ki Barak Panji Sakti.

Dibawah bendera kerajaan Anglurah Ki Barak Panji kepentingan rakyat diprioritaskan, serta didukung dengan pola tata pemerintahan yang baik sehingga dia benar-benar mendapat tempat di hati rakyatnya, berwibawa, arif dan bijaksana. Selama pemerintahannya, dia pun secara terus menerus mengembangkan daerah kekuasaanya hingga pada akhirnya seluruh wilayah Bali Utara (Buleleng) dikuasainya. Belum merasa puas dengan kekusaannya di Bali Utara, Ki Barak terobsesi untuk melakukan perluasan kekuasaan sampai ke Pulau Jawa. Beberapa wilayah di Pulau Jawa yang berhasil di taklukan adalah wilayah Blangbangan yang dipimpin oleh raja yang bernama Ki Pasung Gerigis. 
Saat ini luas wilayah Desa Panji adalah $1061 \mathrm{Ha}$ dan terletak pada ketinggian 20m$650 \mathrm{~m}$ diatas permukaan laut. Sementara batas-batas Desa Panji sendiri yaitu

1. Sebelah Utara : Desa Bhaktiseraga

2. Sebelah Selatan : Desa Wanagiri

3. Sebelah Barat : Desa Panji Anom

4. Sebelah Timur : Desa Sambangan

Struktur organisasi adalah suatu susunan dan hubungan antara tiap bagian serta posisi yang ada pada suatu organisasi dalam menjalankan kegiatan operasional untuk mencapai tujuan yang diharapkan dan diinginkan. Struktur organisasi menggambarkan dengan jelas pemisahan kegiatan pekerjaan antara yang satu dengan yang lain dan bagaimana hubungan aktivitas dan fungsi dibatasi. Dalam struktur organisasi yang baik harus menjelaskan wewenang siapa melapor kepada siapa, jadi ada satu pertanggungjawaban apa yang di kerjakan. Struktur organisasi menspesifikasikan pembagian kerja dan menunjukkan bagaimana fungsi atau aktivitas yang beraneka ragam yang dihubungkan sampai batas tertentu, juga menunjukkan tingkat spesialisasi aktivitas kerja (Suranto, 2005: 85). Struktur organisasi adalah sesuatu yang harus dimiliki oleh organisasi, baik organisasi tersebut besar atau kecil. Struktur organisasi berkaitan dengan hubungan yang relatif tetap di antara berbagai tugas yang ada dalam organisasi. Menurut Ervianto (2002), pengertian bentuk organisasi yang paling sederhana adalah bersatunya kegiatan-kegiatan dari dua individu atau lebih dibawah satu koordinasi, dan berfungsi mempertemukan mereka menjadi satu tujuan. Fungsi organisasi yang kompleks adalah mengubah sesuatu melalui suatu tatanan terkoordinasi yang mampu memberikan nilai tambah, sedemikian rupa sehingga memungkinkan organisasi mencapai tujuannya dengan baik. Menurut Robbins (2002), Organisasi merupakan struktur koordinasi terencana yang formal, melibatkan dua orang atau lebih, dalam rangka mencapai tujuan bersama. Struktur organisasi menjelaskan bagaimana tugas kerja akan dibagi, dikelompokan, dan dikoordinasikan secara formal. Struktur organisasi adalah kerangka kerja formal organisasi mana tugas-tugas pekerjaan dibagi-bagi, dikelompokkan, dan dikoordinasikan. Pembentukan struktur organisasi menurut Gitosudarmo dan Sudita (200:240) menghadapi dua hal pokok, pertama, deferensiasi atau pembagian tugas di antara para anggota organisasi, dan kedua integrasi atau koordinasi atas apa yang telah dilakukan dalam pembagian tugas tersebut. Tujuan dari dibentuknya struktur organisasi tidak lain adalah untuk mengetahui tugas dan wewenang yang dimiliki oleh masing-masing orang dalam organisasi tersebut, khususnya bagi pengurus organisasi. Dari hasil wawancara dan observasi, Nyoman Sutama selaku Kepala Desa memaparkan mengenai struktur organisasi desa,

Struktur organisasi penting, karena adanya struktur disanakan terlihat terjadinya pembagian tugas pokok dan fungsi, tanpa struktur sulit menentukan tugas pokok dan fungsi di sana, ada ketua, wakil ketua, sekretaris dan anggota. Ketua tugas pokoknya apa, dan juga sebagai jenjang untuk mengadakan koordinasi. Struktur organisasi di sudah terintegritas, karena sudah disahkan oleh bupati. Sistem perekrutan anggotanya dengan berkoordinasi bersama kepala desa, kelian dusun, dimana kepala dusun maupun perbekel melirik siapa sih di daerah itu yang bisa mewakili daerah itu, dilihat juga keatifannya untuk desa dan berdasarkan rekomendasi dari kadus.

Jika dihubungkan antara teori dan hasil pemaparan informan di dalam hasil observasi dan wawancara dapat diambil kesimpulan bahwa struktur organisasi adalah dengan adanya struktur organisasi yang jelas maka secara langsung akan mempengaruhi perkembangan organisasi itu sendiri karena dengan adanya struktur organisasi yang jelas akan lebih memudahkan organisasi itu sendiri di dalam menjalankan aktivitasnya sehari-hari. Menurut Roberts dan Hunt (1991), suatu organisasi dimulai dengan suatu tujuan. Sekelompok orang membentuk suatu kelompok atau organisasi untuk suatu tujuan. Bisa dikatakan juga bahwa organisasi dibentuk atas dasar kesesuaian maksud atau ketertarikan dari beberapa individu yang berkumpul bersama untuk mencapai tujuan tertentu. Orang membentuk organisasi karena menyadari bahwa dengan organisasi dapat menambah kemampuan melalui bekerjasama dengan orang lain. Dalam suatu organisasi sebaiknya ada pembagian tugas 
dan tenaga kerja. Pembagian ini menguntungkan karena dengan ada pembagian tugas dan tenaga kerja, kemampuan masing-masing individu dapat digunakan dengan optimal. Pembagian ini menghasilkan suatu struktur organisasi yang akan membutuhkan suatu koordinasi. 
Jurnal IImiah Akuntansi dan Humanika, Vol. 9 No. 1, April 2019 ISSN: 2599-2651

\section{Struktur Organisasi Desa Panji}

Struktur Organisasi Tata Kerja Pemerintahan Desa Panji Dan Perangkatnya

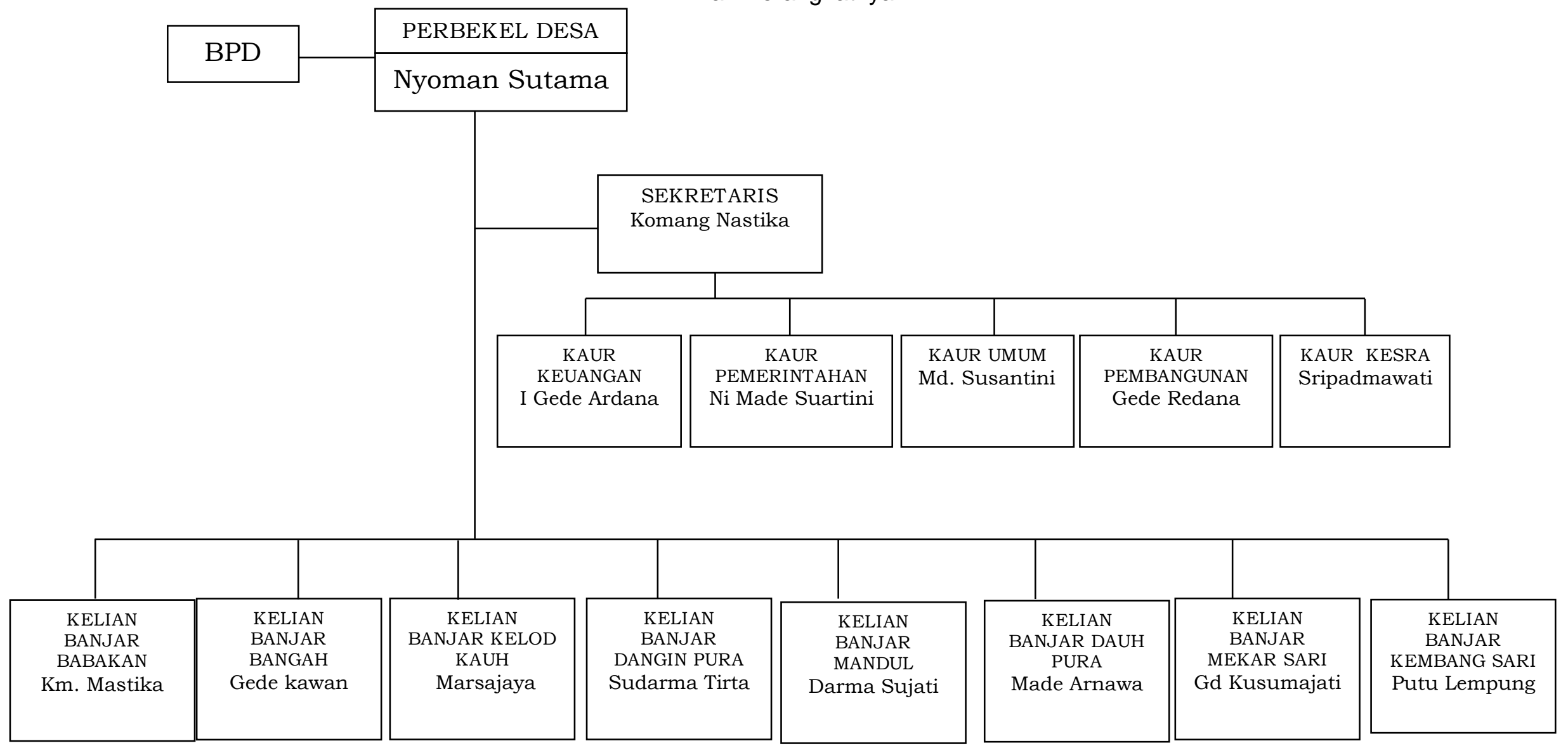


Visi dan Misi Desa Panji

Visi: Membangun serta mewujudkan masyarakat madani yang berdasarkan pancasila dan UUD 1945

Misi:

1. Membangun sebuah tata pemerintah desa yang bersih dan berwibawa serta bebas dari praktik kolusi, korupsi dan nepotisme.

2. Melayani kepentingan masyarakat dibidang administrasi pemerintahan.

3. Mengedepankan sebuah pelayanan yang cepat, tepat, dan akurat.

\subsection{Eksistensi Nilai-Nilai Budaya Kebersamaan dalam Pembangunan untuk Praktik Akuntansi atau Pengelolaan Keuangan di Desa Panji}

Dalam hasil observasi dan wawancara mengenai eksistensi nilai budaya kebersamaan dalam pembangunan untuk praktik akuntansi atau pengeloaan keuangan di Desa Panji Nyoman Sutama (Kepala Desa) memaparkan pernyataan sebagai berikut,

Setiap pengelolaan dana desa harus didasari dengan visi dan misi. Visi dari desa panji yaitu membangun serta mewujudkan masyarakat madani yang berdasarkan Pancasila dan UUD 1945. Jadi setiap pengelolaan dana desa harus dilandasi dengan visi tersebut. Seperti halnya nilai yang terkandung dalam goak-goakan mengandung nilai kebersamaan dalam pembangunan, dan di visi pun telah tercantum mengenai semangat pembangunan. Sementara bersama yang dimaksud yaitu kebersamaan pemerintah dan masyarakat Desa Panji.

Hal ini juga diperkuat oleh Kelian Tempek yaitu Ketut Nara dalam hasil observasi dan wawancara sebagai berikut,

Tarian megoak-goakan ini sangat mengakar di Desa Panji. Sejak dulu telah ditarikan. Dalam acara penting apapun akan dilaksanakan tarian megoak-goakan. Sehari setelah raya Nyepi biasanya tarian ini akan ditarikan. Selain itu digunakan juga untuk penyambutan akan tetapi tarian goak-goakan untuk penyambutan ini berbeda dengan yang ditarikan pada hari raya Nyepi. Budaya ini ada pengaruhnya dengan pengelolaan keuangan desa. Jika dilihat dari segi sejarahnya yang berhubungan dengan Ki Barak Panji Sakti yaitu tarian megoakgoakan ini dalam tariannya terdapat tokoh Raja, Patih dan Putri. Tarian megoak-goakan ini mengandung nilai persatuan dan nilai kebersamaan dalam membangun. Seperti halnya di desa Panji yaitu gotong royong yang sering disebut "Ngayah". Pemerintah dan masyarakat sama-sama terlibat dalam pembangunan infrastruktur desa melalui dana swadaya masyarakat Desa Panji dan bantuan dana dari pemerintah, seperti halnya pengelolaan air bersih dan pengelolaan air di subak.

Hal ini senada dengan apa yang dipaparkan oleh Gede Ganesha selaku salah satu informan dalam penelitian yang dilakukan oleh peneliti di Desa Panji,

Budaya pasti mempengaruhi perilaku manusia. Makna yang terkandung dalam tarian megoak-goakan adalah kebersamaan secara ekonomi seperti koperasi, LPD yang menerapkan nilai gotong royong dalam mengoperasikan koperasi itu sendiri. Seperti cerita di goak-goakan rajanya berbagi kepada rakyatnya dimana setiap orang yang berhasil menangkap ekor goak akan diberikan hadiah, dan bisa memilih hadiah sesuai keinginnya seperti emas, tanah, dan lain-lain. Selain itu, dalam tarian tersebut semua rakyat menjadi goak, kemudian raja mengambil giliran terakhir menjadi goak. Pemimpin lebih mengutamakan kepentingan rakyatnya seperti halnya hubungan pemerintahan dengan masyarakat, yang seharusnya lebih mementingkan kepentingan masyarakat dahulu dari pada kepentingan pemerintah. Dalam mengelola keuangan harus sesuai nilai-nilai tersebut, seperti mengutamakan kepentingan rakyat serta menggunakan dana untuk kepentingan desa dan masyarakat. Zaman sekarang ini manusia banyak yang bersifat apatis, kurang memperhatikan lingkungan sekitar. Dana desa yang dimanfaatkan untuk pembangunan desa berasal dari usulan-usulan masyarakat yang aspirasi dihimpun dalam musrenbang (musyawarah perencanaan pembangunan). Akan tetapi tidak semua usulan masyarakat diterima dan dapat direalisasi. Usulan dari masyarakat tersebut dipilih yang sesuai dengan visi dan misi desa agar dapat direalisasikan. Dari musrenbang dapat di gambarkan sebagai 
nilai-nilai budaya megoak-goakan tersebut. Dalam pengelolaan dana desanya semua perencanaan dalam dana desa telah disesuaikan dengan hasil musrenbang. Maka diperencanaan dalam pengelolaan dana desa telah sesuai dengan nilai-nilai yang terkandung dalam tarian megoak-goakan.

Hal ini diperkuat kembali oleh Kelian Banjar Kelod Kauh yaitu Nyoman Marsajaya dalam hasil observasi dan wawancara sebagai berikut,

Nilai yang terkandung dan satu yang poin penting ada nilai persatuan, nilai kekompakan sehingga dapat membangkitkan solidaritas pemuda dan masyarakat. Tujuannya dengan kedepannya jika itu bisa dimaknai oleh masyarakat panji khususnya, dapat membawa dampak yang baik sekali dalam meningkatkan ekonomi masyarakat lewat permainan megoak-goakan jika dikembangakan bisa menciptakan desa wisata nantinya. Nilai-nilai persatuan yang paling penting karena dalam penyerangan ke Blambagan, kalau tanpa persatuan tidak akan bisa mengalahkan Blambangan. Mengenai masalah penyaluran dana desa, pembangunannya harus swakelola harus swadaya oleh masyarakat, akan tetapi yang bisa hanya beberapa hal saja. Perbaikan jalan bisa dipakai untuk (implementasi) semangat untuk mebangun bersama itu bisa. Jika proyek pembangunan pembuatan drainase/got tidak bisa dikerjakan secara swakelola karena tidak semua penduduk panji berprofesi sebagai tukang, ada sebagian yang berprofesi sebagai Pegawai Negeri Sipil (PNS) sehingga tidak bisa untuk ikut pembangunan got jika pembangunan jalan bisa semua karena membutuhkan banyak tenaga. Untuk semangat gotong royong masih disini (masih terdapat di Desa Panji)

Dari pernyataan informan diatas dapat diambil kesimpulan bahwa terdapat pengaruh antara nilai-nilai budaya kebersamaan dalam pembangunan untuk praktik akuntansi atau pengelolaan keuangan di Desa Panji. Masing-masing budaya yang ada di Bali merupakan hasil cipta, rasa, dan karsa sehingga sangat rentan mempengaruhi pola dan interaksi pada pemerintah desa utamanya dalam pengelolaan mengenai akuntansi atau keuangan pasca penggunaan anggaran desa.

\subsection{Prosedur Budaya Megoak-goakan Mempengaruhi Praktik Akuntansi atau Pengelolaan Keuangan di Desa Panji}

Megoak-goakan adalah sebuah permainan rakyat yang kini hanya masih dapat disaksikan khusus dihari Nyepi di Desa Panji Kecamatan Sukasada kabupaten Buleleng. Permainan megoak-goakan merupakan persiapan I Gusti Barak Panji untuk penyerangan negeri Blambangan nantinya disaat beliau menduduki tahta di puri Sukasada dan setelah Ida Peranda Sakti Ngurah Pemada sebagai Bhagawanta Puri serta kehadiran Arya Pande Swarna di Sukasada yang telah mempunyai 2000 orang prajurit dipimpin oleh panglima Kyayi Macan Gading. Megoak-gokan dilihat menurut termologi ada hal yang tersembunyi dari sebuah metode ajakan kepemimpinan I Gusti Barak Panji dalam kebersahajaannya namun mengandung filsafat yang mendalam untuk mengajak rakyat Denbukit dalam mempertahankan eksistensi kerajaan denbukit dan kebersamaan dalam pembangunan. Goak-goakan diambil dari kata "Goak" nama dari seekor burung (gagak) dalam bahasa Kawi disebut "Kanganila" (Goak-selem-burung gagak hitam) merupakan konsep kepemimpinannya. Burung gagak adalah burung yang hidupnya berkelompok yang Nampak senang bermain saling kejar dan saling sambar biasanya di sebuah kuburan disaat pohon Kepuh sedang berbunga mereka bernyanyi bersama dan bersorak "gaaak.....gaaak....." senang melihatnya disaat-saat tertentu kehadirannya dengan nyanyiannya membuat yang mendengar merakan ketakutan, kecemasan, menganggapnya datang menyampaikan berita duka, Gagak si burung peramal yang menyampaikan kepada seseorang tentang datangnya kemalangan nantinya. Oleh karenanya I Gusti Barak Panji penganut kepemimpinan (burung Gagak) akan selalu bersabar dalam menghitung-hitung waktu, ia bersikap penyabar dan tidak terburu nafsu. la berpikir pasti (Wicaksanayang naya) yang selalu bercermin dari masa lalu (Atita), untuk pengambilan keputusan yang tepat pada masa kini (Wartamana), dan mampu memprediksi apa yang bakal terjadi (Nagata). Hari kematian sudah pasti, sehingga mati tidak perlu ditakutkan, bila untuk menjalankan misi suci (wajib bela negara) tidak perlu ragu namun kematian sia-sia harus dihindari. 
Permainan megoak-goakan dikemas I Gusti Barak Panji dalam pemahaman yang mengandung kedalam makna etis filosifis dalam membawakan misi suci. Dari jumlah 2000 prajurit diseleksi secara teliti untuk direkrut menjadi "Teruna Goak" dan setelah jadinya dibagi menjadi dua kelompok yang dipimpin oleh Pelheber (Pangliman) I Sampun dan I Made Batan (dikenal dengan sebutan Goak Tambang dan Goak Batan). Permainan ini digelar dalam berbulan-bulan sambil menghitung hari dan menunggu telik sandhi (matamata) yang dikirim, kembali dari negeri Blambangan. Sudah berapa pemain goak telah berganti, demikian pula ekor ular menggantikan pemeran goak dan berapa banyak pembagian hadiah yang diterimakan bersama dengan pemberian keris-keris, tombak peralatan perang yang dibuat oleh para pande dan penataan ukiran seperti danganan keris bertahtakan permata intan berlian berlapis emas. Dari Arya Pande Swarna dam dipasupati oleh Ida Pranda Sakti Ngurah Pemada membuat terkenal pajenengan Buleleng (keristombak dan senjata lainnya) disebut sebagai pekaryan Ida sangf Bhagawan Grya Banjar Ambengan. Hari yang ditunggu pun telah tiba bersamaan waktu kedatangan telik sandi, I Gusti Ngurah Panji yang selalu berperan menjadi kepala ular mengambil peran goak dengan ungkapan dialog seperti: Teruna: "goak apa budimu" (apa yang kau inginkan?)

(Teruna dan panjak Denbukit merasa ketakutan terhadap Ki Barak Panji junjungan lama terdiam dan tidak memberikan jawaban, mereka bertanya-tanya apa mereka mampu mempersembahkan akan apa kehendak junjungan, (dengan suara terbata-bataa menahan hasrat .....)

Panji menjawab: "manira apti elawan bhumi ngaran ing bhumi Brambangan didinya kawawa de manira"

Ucapan I Gusti Barak Panji sebuah sabda sang nata ratu merupakan "ikrar"nya puluhan tahun lalu yang memang telah lama ditunggu-tunggu rakyat Denbukit terkomando berseru bersorak membana "gaaaak....gaaaak..... gebug Blambanganne.......". Tepat ditahun 1648 mereka berangkat berjuang menggempur bumi Blambangan.

Dari hasil observasi dan wawancara beberapa informan menyampaikan hal sebagai berikut yang pertama, yaitu informan utama yang dalam konteks penelitian adalah Kepala Desa Panji atas nama Nyoman Sutama memaparkan prosedur budaya megoak-goakan mempengaruhi praktik akuntansi atau pengelolaan keuangan di Desa Panji,

Budaya yang terkenal di Desa Panji, Megoak-goakan. Terlihat sekali dalam tarian itu nilai kebersamaan yang sangat mempengaruhi perilaku masyarakat Desa Panji. Contohnya kebersamaan dalam membangun. Sehingga dalam pengelolaan dana-dananya dilakukan secara musyawarah dan atas usulan masyarakat Desa Panji.Dari budaya tersebut akan mempengaruhi sikap masyarakat dan begitu juga saya sebagai masyarakat Desa Panji.

$\mathrm{Hal}$ ini senada dengan penyataan informan utama, yang secara langsung dipaparkan oleh Sekertaris Desa yaitu Komang Nastika pada hasil observasi dan wawancara awal sebagai berikut,

Tarian megoak-goakan adalah budaya yang telah ada sejak dulu di Desa Panji. Sebagai budaya yang menjadi budaya khas Desa Panji maka telah dilakukan pemberdayaan dengan desa menganggarkan dana untuk pemberdayaan tersebut. Seperti setiap Hari Raya Nyepi diselenggarakan pementasan tarian megoak-goakan yang dana kegiatan tersebut berasal dari APBDes. Selain itu, Desa Panji juga mempunyai kegiatan tahunan seperti Porsenides yang sumber dananya berasal dari dana desa.

Berbeda pula dengan yang disampaikan oleh Kelian Banjar Kelod Kauh, Marsajaya terdapat kesamaan dengan kedua informan diatas yang dipaparkan dalam kajian riset penelitian sebagai berikut,

Dilihat dari poin penting nilai persatuan yang terkandung dalam megoak-goakan menurut saya tentu saja dapat mempengaruhi perilaku masyarakat Desa Panji tapi kalau dengan akuntansi saya kurang mengetahuinya.

Tarian ini sudah ada di Desa Panji sejak dulu sehingga nilai yang terdapat dalam tarian ini sudah tertanam dalam masyarakatnya. Di mana nilai persatuan adalah yang paling penting karena dalam penyerangan ke Blambangan, jika tidak ada persatuan tidak akan bisa mengalahkan Blambangan. Masyarakat Desa Panji sudah menjalankan nilai persatuan ini 
dilihat dari perbaikan jalan yang dilakukan secara swakelola yang mencerminkan semangat membangun bersama. Gotong-royong juga masih dijalankan.

Hal ini juga diperkuat oleh pernyataan informan pendukung lainnya yaitu kelian tempek Ketut Nara yang memaparkan pendapatnya sebagai berikut,

Bapak kurang tau terhadap hal tersebut. Tetapi, budaya megoak-goakan ini sudah sangat mengakar di Desa Panji. Jika dilihat dari sejarahnya yang berhubungan dengan Ki Barak Panji Sakti yaitu tarian megoak-goakan ini di dalamnya terdapat tokoh Raja, Patih, dan Putri. Ada makna yang terkandung di dalam tarian ini seperti Nilai Persatuan, Kebersamaan Pembangunan. Seperti halnya di Desa Panji yaitu gotong royong atau dalam istilah Bali disebut ngayah.Mungkin seperti yang bapak bilang tadi bahwa gotong royong atau ngayah tersebut yang bisa mempengaruhi.Karena makna yang terkandung dari tarian megoak-goakan.

Senada dengan pernyataan informan-informan lainnya, pernyataan dari masyarakat Gede Ganesha yang menyatakan sebagai berikut,

Setelah saya baca dan tanya-tanya ke teman-teman saya bahwa budaya dapat mempengaruhi praktik akuntansi. Dana desa yang dimanfaatkan untuk pembangunan desa berasal dari usulan-usulan masyarakat yang aspirasi dihimpun dalam musrenbang (musyawarah perencanaan pembangunan). Akan tetapi tidak semua usulan masyarakat diterima dan dapat direalisasi. Usulan dari masyarakat tersebut dipilih yang sesuai dengan visi dan misi desa agar dapat direalisasikan. Dari musrenbang dapat digambarkan sebagai nilai-nilai budaya megoak-goakan tersebut. Dalam pengelolaan dana desanya semua perencanaan dalam dana desa telah disesuaikan dengan hasil musrenbang. Maka diperencanaan dalam pengelolaan dana desa telah sesuai dengan nilai-nilai yang terkandung dalam tarian megoak-goakan. Praktik dilihat dari faktanya. Seperti sudah adanya koperasi dan KUD (Koperasi Unit Desa) di Desa Panji. Selain itu, di Desa Panji juga sudah mempunyai BUMDes (Badan Usaha Milik Desa) yang bergerak dibidang penyaluran air bersih untuk masyarakat Desa Panji. Di mana melalui BUMDes ini Desa Panji memiliki PAD (Pendapatan Asli Daerah), yang faktanya tidak semua desa di Kecamatan Sukasada memiliki BUMDes.

Untuk lebih jelas dan memperkuat kutipan wawancara diatas, berikut peneliti memaparkan prosedur budaya goak-goakan yang mempengaruhi akuntansi di Desa Panji dengan flowchart sebagai berikut. 


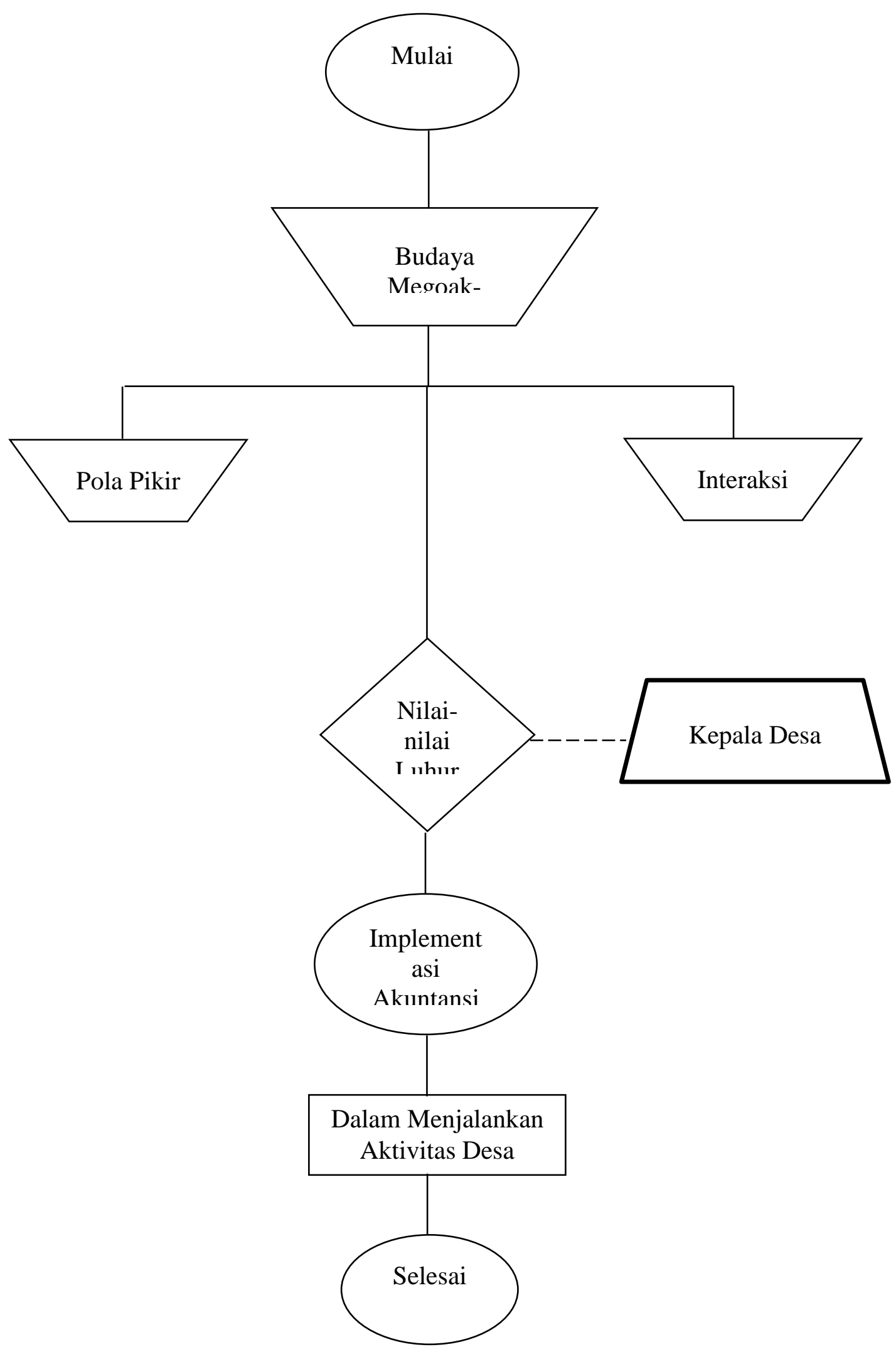

Budaya megoak-goakan merupakan budaya lokal di Desa Panji yang mempengaruhi pola pikir dan interaksi masyarakat Desa Panji. Budaya tersebut mempengaruhi pola pikir dan interaksi masyarakat karena tarian ini dipentaskan setiap momen-momen tertentu 
seperti saat sehari setelah perayaan hari raya Nyepi. Dalam budaya megoak-goakan terdapat nilai-nilai luhur seperti nilai kebersamaan dalam pembangunan dan nilai gotongroyong yang telah diotorisasi oleh Kepala Desa Panji bahwa ada pengaruh budaya lokal terhadap akuntansi. Nilai nilai luhur tersebut diimplementasikan dalam praktik akuntansi ini dibuktikan dalam pelaporan pertanggungjawaban anggaran desa.

\section{Simpulan dan Saran}

Dari hasil dan pembahasan di atas, dapat diambil beberapa simpulan sebagai berikut:

a. Budaya megoak-goakan sangat berpengaruh terhadap eksistensi penerapan akuntansi secara umum baik dilihat secara teoritis dan praktis.

b. Peranan megoak-goakan dalam akuntansi adalah budaya tersebut mempengaruhi pola pikir dan interaksi masyarakat karena terdapat nilai-nilai luhur seperti nilai kebersamaan dalam pembangunan dan nilai gotong-royong. Nilai nilai luhur tersebut diimplementasikan dalam praktik akuntansi ini dibuktikan dalam pelaporan pertanggungjawaban anggaran desa.

c. Tarian megoak-goakan ini telah ada sejak dulu dan ditarikan pada berbagai perayaan dan penyambutan tamu. Karena kebiasaan ini telah lama dilakukan, maka nilai-nilai dalam tarian ini telah melekat pada masyarakat Desa Panji. Dalam penelitian ini terdapat nilai sosial dan nilai agama (religius). Nilai sosialnya tercermin dari perilaku masyarakat Desa Panji yang masih menjalankan prinsip gotong royong dalam kehidupan bermasyarakat. Nilai religius dari tarian ini dapat dilihat ketika akan mementaskan tarian ini, Teruna Goak melakukan persembahyangan terlebih dahulu di Pura Pajenengan yang dipercaya merupakan tempat peristirahatan Ki Barak Panji Sakti.

Berdasarkan pemaparan diatas, saran yang dapat diberikan yaitu seharusnya informan harus ada di tempat penelitian dan memberikan informasi yang lebih lengkap.

\section{DAFTAR PUSTAKA}

Anonim. 2016. Budaya. Tersedia pada https://id.m.wikipedia.org/wiki/Budaya. Diakses tanggal 16 Desember 2016.

Anonim. 2016. Panji, Sukasada, Buleleng. Tersedia pada https://id.wikipedia.org/wiki/Panii, Sukasada, Buleleng. Diakses tanggal 16 Desember 2016.

Kusuma, agiest. 2013. Teori Perilaku Konsumen. Tersedia pada http://netrals.blogspot.co.id/2013/12/teori-perilaku-konsumen.html?m=1 Diakses tanggal 6 Desember 2016.

http://sukasada.bulelengkab.go.id/

Seputar Pengetahuan.2015. 11 Pengertian Budaya Menurut Para Ahli Lengkap. Tersedia pada http://www.seputarpengetahuan.com/2015/03/pengertian-budaya-menurut-paraahli-lengkap.html. Diakses tanggal 16 Desember 2016.

Sinarwati,dkk. 2013. Akuntansi Keuangan 1: Singaraja. Universitas Pendidikan Ganesha

Zaitul.2003.Tinjauan Kritis tentang Pengaruh Budaya Terhadap Sistem Akuntansi. Fakultas Ekonomi Universitas Bung Hatta. 